\title{
Econometric Analysis on Development of Mining Industry in Zhanjiang
}

\author{
Yanli $\mathrm{Xu}^{1,3}$ and Dan $\mathrm{Liu}^{2,3,{ }^{*}}$ \\ ${ }^{1}$ School of Business, Lingnan Normal University, Zhanjiang, Guangdong, 524048, P. R. China \\ ${ }^{2}$ Liabrary, Lingnan Normal University, Zhanjiang, Guangdong, 524048, P. R. China \\ ${ }^{3}$ South China Sea Silk Road Collaborative Innovation Centre, Lingnan Normal University \\ ${ }^{*}$ Corresponding author: liudan100liudan@163.com
}

\begin{abstract}
Keywords: Gross annual value of mining industry; Total fixed assets investment; Overall industrial energy consumption; Zhanjiang
\end{abstract}

\begin{abstract}
In order to study the influence factors to the gross annual value of Zhanjiang's mining industry, this paper uses econometrics method to establish an econometric model and obtains a regression equation of the total fixed assets investment and the overall industrial energy consumption to the gross annual value of Zhanjiang's mining industry. From the analysis results, fixed asset investment has a greater influence on the mining industry.
\end{abstract}

\section{Introduction}

Zhanjiang, as the southernmost port city in Mainland China, owns superior geographical location, excellent harbors and has abundant mineral resources. So far, 33 types of mineral reserves and 155 mineral deposits have been discovered, the most valuable among which is the "Four Soil" resource (diatomite, bentonite, moor soil, kaoline, etc.) the continental shelf basin of the northern South China Sea, which borders on Zhanjiang, is one of the four major offshore oil and gas accumulation centers in the world. Though with abundant products, the abundant resources have not been properly exploited. The mining industry in Zhanjiang is still in its early phase. Compared to other cities with considerable resource conditions, there is still much space for the development of Zhanjiang's mining industry.

Zhanjiang has depended mainly on importing minerals for a long time. With the operation of the large-scale bulk-cargo terminal of Zhanjiang Port and the investment of Baosteel on the Zhanjiang's steel project, the transaction of ironstone in Southern China has become increasingly active.

According to statistics, $90 \%$ of the world's energy and $80 \%$ of industrial raw materials come from mineral raw materials. Mineral resources are the prerequisite for regional economic booms and the important symbol for economic strength. As part of Zhanjiang's economic composition, the mining industry is, to some extent, related to Zhejiang's economic construction and the pace and speed of the rise of Zhanjiang in Guangdong and even in the whole country. Therefore, this paper adopts the related data in the recent years to conduct research and analysis on the gross annual value of Zhanjiang's mining industry, the fixed assets investment and the energy consumption by establishing an econometric model to find the deficiencies and propose corresponding suggestions, which is of great significance for the development of Zhanjiang's mining industry and its economy.

\section{Model Setting and Data Specification}

The basic factors that influence the gross annual value of Zhanjiang's mining industry are mainly the total fixed assets investment and the overall industrial energy consumption (including water, electricity, etc.). Set $\mathrm{Y}$ as the gross annual value, $\mathrm{X} 1$ as the total fixed assets investment, $\mathrm{X} 2$ as the overall industrial energy consumption. For these three do not display a linearity relationship, the econometric model is established as follow:

$$
\ln Y_{t}=\beta_{0}+\beta_{1} \ln X_{1 t}+\beta_{2} \ln X_{2 t}+\mu_{t}
$$


Inquire related data from May 2014 to August 2016 from Zhanjiang Statistical Information Net, the following data can be obtained by calculation and collation:

Table 1 Influence Factors to the Gross Annual Value of Zhanjiang's Mining Industry

\begin{tabular}{|c|c|c|c|}
\hline Month-year & $\begin{array}{r}\text { gross annual value }(\mathrm{Y}) \\
\text { (Ten thousand yuan) }\end{array}$ & $\begin{array}{r}\text { total fixed assets } \\
\text { investment (X1) (Ten } \\
\text { thousand yuan) }\end{array}$ & $\begin{array}{r}\text { overall industrial energy } \\
\text { consumption (X2) }\end{array}$ \\
\hline May-2014 & 5965.00 & 13513.13 & 2690.96 \\
\hline Jun-2014 & 10245.00 & 15091.73 & 3024.31 \\
\hline Jul-2014 & 11658.00 & 28020.96 & 7419.01 \\
\hline Aug-2014 & 12423.00 & 29756.44 & 952.90 \\
\hline Sep-2014 & 17547.00 & 40418.54 & 1035.33 \\
\hline Oct-2014 & 18606.00 & 42486.27 & 1162.44 \\
\hline Nov-2014 & 19483.00 & 45275.63 & 1196.92 \\
\hline Dec-2014 & 20468.00 & 59148.75 & 1553.36 \\
\hline Jan-2015 & 20554.00 & 63485.06 & 1576.35 \\
\hline Feb-2015 & 20554.00 & 69150.58 & 1576.35 \\
\hline Mar-2015 & 23955.00 & 83762.02 & 1599.34 \\
\hline Apr-2015 & 25184.00 & 91554.02 & 1873.32 \\
\hline May-2015 & 25549.00 & 91904.96 & 2004.33 \\
\hline Jun-2015 & 28186.00 & 105511.73 & 2161.27 \\
\hline Jul-2015 & 28808.00 & 111539.04 & 2384.90 \\
\hline Aug-2015 & 28808.00 & 109730.13 & 2235.37 \\
\hline Sep-2015 & 33955.00 & 122417.90 & 2454.34 \\
\hline Oct-2015 & 34398.00 & 129772.17 & 2531.86 \\
\hline Nov-2015 & 34545.00 & 129823.02 & 2690.61 \\
\hline Dec-2015 & 55661.00 & 146444.17 & 2730.41 \\
\hline Jan-2016 & 61215.00 & 152920.90 & 2857.62 \\
\hline Feb-2016 & 71954.00 & 154454.17 & 3544.09 \\
\hline Mar-2016 & 85078.00 & 172981.08 & 3544.09 \\
\hline Apr-2016 & 85788.00 & 180947.75 & 3557.01 \\
\hline May-2016 & 88954.00 & 201039.92 & 3609.07 \\
\hline Jun-2016 & 95875.00 & 211992.17 & 3724.87 \\
\hline Jul-2016 & 119312.00 & 212155.25 & 3725.25 \\
\hline Aug-2016 & 137393.00 & 273017.83 & 3735.32 \\
\hline
\end{tabular}

Data Sources: Zhanjiang Bureau of Statistics

\section{Parametric Estimation and Results of Model}

Based on the above data and adopt Eviews, the regression results are as follows: 


\begin{tabular}{|c|c|c|c|c|c|c|c|c|}
\hline View & Proc & Object & Print & Name & Freeze & Estimate & Forecast Stats $\mathrm{R}$ & Resids \\
\hline \multicolumn{9}{|c|}{$\begin{array}{l}\text { Dependent Variable: LOG(Y) } \\
\text { Method: Least Squares } \\
\text { Date: } 12 / 30 / 16 \text { Time: } 11: 30 \\
\text { Sample (adjusted): } 2014 \mathrm{M} 05 \text { 2016M10 } \\
\text { Included observations: } 28 \text { after adjustments }\end{array}$} \\
\hline \multicolumn{4}{|c|}{ Variable } & \multicolumn{2}{|c|}{ Coefficient } & Std. Error & $\mathrm{t}$-Statistic & Prob. \\
\hline \multicolumn{4}{|c|}{$\begin{array}{c}\text { C } \\
\text { LOG(X1) } \\
\text { LOG(X2) }\end{array}$} & \multicolumn{2}{|c|}{$\begin{array}{r}-1.641441 \\
0.896773 \\
0.235662\end{array}$} & $\begin{array}{l}0.93536 \\
0.06774 \\
0.11391\end{array}$ & $\begin{array}{r}-1.754869 \\
13.23686 \\
2.068793\end{array}$ & $\begin{array}{l}0.0915 \\
0.0000 \\
0.0491\end{array}$ \\
\hline \multicolumn{4}{|c|}{$\begin{array}{l}\text { R-squared } \\
\text { Adjusted R-squared } \\
\text { S.E. of regression } \\
\text { Sum squared resid } \\
\text { Log likelihood } \\
\text { F-statistic } \\
\text { Prob(F-statistic) }\end{array}$} & \multicolumn{2}{|c|}{$\begin{array}{r}0.902399 \\
0.894591 \\
0.259028 \\
1.677385 \\
-0.320717 \\
115.5727 \\
0.000000\end{array}$} & \multicolumn{3}{|c|}{$\begin{array}{ll}\text { Mean dependent var } & 10.38206 \\
\text { S.D. dependent var } & 0.797825 \\
\text { Akaike info criterion } & 0.237194 \\
\text { Schwarz criterion } & 0.379930 \\
\text { Hannan-Quinn criter. } & 0.280830 \\
\text { Durbin-Watson stat } & 0.669227\end{array}$} \\
\hline
\end{tabular}

Figure 1. Econometric Analysis Results

The econometric equation is:

$$
\ln \hat{Y}=-1.6414+0.8968 \ln \mathrm{X}_{1}+0.2357 \mathrm{X}_{2}
$$

The regression results show that $90 \%$ of the variation of the gross annual value of Zhanjiang's mining industry can be explained by the variation of the total fixed assets investment and the overall industrial energy consumption from May 2014 to October 2016.

\section{Conclusion}

The model estimation results show that, on average, the gross annual value of mining industry will increase by $0.897 \%$ if fixed assets investment increase $1 \%$; the gross annual value of mining industry will increase by $0.236 \%$ if the overall industrial energy consumption increase $1 \%$ (assuming other variables remain unchanged). From the results, fixed assets investment has a greater impact on the mining industry.

\section{Acknowledgements}

It is a pleasure to acknowledge the support of the project from XU Yan-li being selected in the introduction of shortage top talent of "Sailing up (Yangfan) project" in Guangdong Province in 2014. The project is Leading Industry Development Strategy Research in Emerging Areas in Western Guangdong for Accelerating the Economic Development of Western Guangdong.

It is a pleasure to acknowledge the support from the talents introduction project of universities in Guangdong Province and from Guangdong University of Petrochemical Technology. The project is the Coordinating Development Model Construction and the Path Research of Technical Capability and Technology Management Capability in Equipment Manufacturing Industry. 
It is a pleasure to acknowledge the support from the talents introduction project of Guangdong University of Petrochemical Technology. The project is Research on the Coordinating Development Model and Path of Technical Capability and Technology Management in Maoming (513088).

It is a pleasure to acknowledge the support from comprehensive reform experiment of the Major of International Economics and Trade in Guangdong University of Petrochemical Technology.

It is a pleasure to acknowledge the support from International Education Department in Guangdong University of Petrochemical Technology. The project is Research on Teaching Quality Evaluation for the Major of International Economics and Trade in English in the Background of International Education (2014GDUPTGJ-07).

It is also a pleasure to acknowledge the support from South China Sea Silk Road Collaborative Innovation Center in Lingnan Normal University (2017EL03).

It is also a pleasure to acknowledge the support from Excellent Course "Macroeconomics" in Teaching Quality and Teaching Reform Project in Lingnan Normal University in 2017 (114961700227).

It is a pleasure to acknowledge the support from the talents introduction project of Lingnan Normal University in 2018. The project is Research on Economic Growth in Underdeveloped Areas.

It is a pleasure to acknowledge the support from Institute of Economic Development of BeiBuWan and Research Center of Economic Development of Coastal Cities in Lingnan Normal University.

\section{References}

[1] Yanli Xu, Dan Liu, etc. Econometric Analysis of Development of Real Estate Industry in Zhanjiang. Advances in Economics, Business and Management Research (ISSN 2352-5428) (ICEM2017), Volume 53, pp29-32.

[2] Yanli Xu, Dan Liu, etc. Econometric Analysis on Development of Grain Industry in Zhanjiang. Advances in Economics, Business and Management Research (ISSN 2352-5428) (ICEM2017), Volume 53, pp714-717.

[3] Yanli Xu, Dan Liu , etc. Econometric Model Analysis of Influencing Factors of Import and Export in Zhanjiang City. Advances in Economics, Business and Management Research (ISSN 2352-5428) (ICEM2017), Volume 53, pp1019-1022.

[4] Yan-Li XU, Ya-Xin WANG, etc. Analysis on Relationship between the Agriculture in Maoming with Local Economic Growth. Advances in Engineering Research (ISSN 2352-5401) (ESM2016), Volume 62, pp226-229.

[5] Yan-Li XU, Ya-Xin WANG, etc. Research on Coordination Development Paths for Technology Capacity and Technology Management Capacity. Advances in Engineering Research (ISSN 2352-5401) (ESM2016), Volume 62, pp222-225.

[6] Yan-Li XU, Ya-Xin WANG, etc. Analysis on the Relationship between the Maoming Industries and Local Economic Growth. 2016 Joint International Conference on Service Science, Management and Engineering (SSME 2016) and International Conference on Information Science and Technology (IST 2016), pp75-80.

[7] Yan-Li XU, Ya-Xin WANG, etc. Research on the Impact of Related Industries on the Total Output Value of Agriculture in Maoming. 2016 Joint International Conference on Service Science, Management and Engineering (SSME 2016) and International Conference on Information Science and Technology (IST 2016), pp81-87. 